\title{
The value of differentiated instruction in the inclusion of students with special needs/ disabilities in mainstream schools
}

\author{
Vasilis Strogilos \\ Early Childhood and Special Needs Education Academic Group, National Institute of Education, Nanyang Technological \\ University, Singapore
}

\begin{abstract}
The aim of this presentation is to analyse the current international policies on inclusion and to discuss the value and use of differentiated instruction as a means to the inclusion of students with special needs/ disabilities in mainstream settings. The movement to inclusion requires teachers to create inclusive learning environments, which would encourage the use of practices that would benefit all students. In this respect, differentiated instruction has rapidly evolved as a teaching approach to meet the diverse and heterogeneous needs of students with special needs/ disabilities in mainstream classrooms. Modifying and adjusting instruction to allow all students in a classroom to access the general education curriculum is at the heart of inclusive education. In this presentation, I shall discuss the development of differentiated instruction as a means to inclusion for students with special needs/ disabilities in mainstream classrooms. Information will be provided with regard to the main principles of DI as well as the basic criteria in designing individualized adaptations for these students. In addition to this, I will review the factors which influence the development of differentiated instruction based on research findings. Finally, I will argue that differentiated instruction provides a learning environment which takes into consideration the individual characteristics of students and, as such, is a useful approach for the inclusion of students with special needs/ disabilities in mainstream settings.
\end{abstract}

\section{Introduction}

Inclusion presupposes a philosophy of acceptance, where all people are valued and treated on equal terms. It is seen as both a base for future school development and an unending process that fosters participation for all students. Inclusion represents school improvement on many levels. As such, it involves the development of practices which aim to reorganize schools as places of equal opportunity for all students to participate and learn. Thus, inclusive education involves changes from the policy and structural level to the level of schooling through changes to the curriculum and teaching strategies. As Booth and Ainscow (2011, p. 9) argue "Inclusion is about increasing participation for all children and adults. It is about supporting schools to become more responsive to the diversity of children's backgrounds, interests, experience, knowledge and skills". Thus, the focus is not merely on the improvement of the skills of the student with special needs/ disabilities, but mainly on the improvement of teaching for all students.

However, international research has shown that the struggle to become inclusive is still in progress and school and social services reform is a major challenge. The Council of Europe (2009, p.46) states that 'inclusion may be understood not just as adding on to existing structures, but as a process of transforming societies, communities and institutions such as schools to become diversity sensitive.'. International and national policies and laws (e.g. Every Child 
Matters, 2004/UK; IDEA, 2004/USA) have charged schools with developing inclusive practices so as to increase participation and improve the quality of education to all students. Schools are encouraged to design and implement practices which are constantly inclusive since the number of students with diverse learning needs is increasing. Ideally, these schools include all students, eliminate differences, support learning and respond to individual needs. However, as Slee (2013, p.2) argues, in spite of 'financial expenditure and optimistic talk exclusion remains a real and present danger'. Evidence exists that the placement of pupils with disabilities at mainstream schools has not been followed by meaningful access to learning (Nind \& Wearmouth, 2006; Scruggs, Mastropieri, \& McDuffie, 2007) even though there is emerging evidence that even students with significant cognitive disabilities can benefit from access to the general education curriculum (Wehmeyer, 2011).

\section{Moving towards inclusive education?}

Many countries have adopted the Salamanca Statement on Principles, Policy and Practice in Special Needs Education and a Framework for Action (UNESCO, 1994) and United Nations Convention on the Rights of Persons with Disabilities (2006). As a result, new policy initiatives have recognized the need to work towards the development of inclusive education. Ideally, these schools include all students, eliminate differences, support learning and respond to individual needs. However, as Stangvik (2010) notes, global policies are heavily dependent on local values. Thus, the implementation of international policies on inclusive education is closely related to the different understandings of disability and the meaning of inclusion in different societies.

Internationally there are different understandings of inclusion and the way in which it can be implemented in practice. These understandings of inclusion could be grouped under two broad approaches: a) the radical restructuring of the education system; and b) the implementation of additional special programmes in the existing arrangements in mainstream settings. The proponents of radical restructuring of the education system believe that such a change could provide appropriate education for all students (Ferguson, 2008; Slee, 2010) and see specialized programmes as a form of exclusion, even within a mainstream setting. For example, Slee (2013) argues that the current policies on inclusion employs mechanisms such as the increased enrolment of students in specific disabilities, which then determines the financial support allocated to schools. This process creates more strangers, more surplus children and thus more exclusion. Contrariwise, those who support the continuation of special programmes believe that special education is a service which needs to remain alive in mainstream settings and that not all students' needs are best served in mainstream schools (Forbes, 2007; Zigmond \& Kloo, 2011). Zigmond and Kloo (2011, p.170) challenge the idea that special education is so not-special that it can be delivered by mainstream teachers. They argue 'that special education will not survive to serve the special needs of students with disabilities if it loses its identity, its special budget allocation, and its unique special requirements'.

Even though, internationally, inclusive education is conceived as a broad reform that welcomes diversity among all learners (Unesco, 2001), it is mainly implemented as programmatic regularities which fail to initiate broad school reforms. Thus, I could argue that inclusive education in many countries has not yet provided a shift in approach from serving children with disabilities within mainstream education settings to a more blended practice through a process of eliminating the barriers to participation and learning experienced by students within the school system. To this end, in this presentation, I will argue that 
differentiated instruction provides a learning environment which takes into consideration the individual characteristics of all students (Janney \& Snell, 2006; Strogilos et al., 2017) and, as such, is a useful approach for the inclusion of students with special needs/ disabilities in mainstream settings.

\section{Differentiated instruction}

Differentiated Instruction involves responding effectively to the differences that exist among learners in the classroom. According to Tomlinson (2001), teachers differentiate when they reach out to an individual or small group by varying their teaching in order to create the best learning experience possible. Differentiated instruction is considered as one of the essential means to effective education for all students including those with disabilities. As Tomlinson argues (2003), differentiation is not associated with "one size fits all" teaching but mainly with responsive teaching. Thus, when teachers differentiate they "proactively plan varied approaches to what students need to learn, how they will learn it, and/or how they will show what they have learned in order to increase the likelihood that each student will learn as much as he or she can, as effectively as possible' (Tomlinson 2003, p. 151).

\section{Research findings on differentiated instruction}

Despite the perceived importance of differentiated instruction, research has indicated the absence or inconsistent use of this strategy. Limited use of differentiated instruction has been noted for 'typically developing' students (Hertberg-Davis, 2009; Van Tassel-Baska, \& Stambaugh, 2005) as well as for students with special needs/ disabilities within mainstream classrooms (Buckley, 2005; Scruggs, Mastropieri, \& McDuffie 2007). At the international level, even though the number of students with SEN in mainstream classrooms has increased, the type and the quality of education they receive remains a contentious issue (Morningstar, Shogren, Lee, \& Born, 2015). Several authors have urged for the necessary modifications to increase the quality of education provided to students with SEN through differentiated instruction (King-Sears, 2008; Kurth \& Keegan, 2014; Lee, Wehmeyer, Soukup, \& Palmer, 2010).

The modifications made to the curriculum are considered an essential inclusive strategy for the education of students with SEN in the general classroom. As Janney and Snell (2006) indicate, modifications may be curricular, instructional or alternative. "Curricular" refer to what is being taught (i.e. content); "instructional" concern alterations of the way instruction takes place (i.e. method); and "alternative" involve altered goals, instruction and activities. According to King-Sears (2008), differentiated instruction has the potential to increase the scores on hightest assessments for students with disabilities, students at-risk for school failure, typical students, and students labelled as gifted and talented in comparison to students in schools that promote 'one size fits all' instruction.

Several factors have been identified in the literature with regard to the absence or inconsistent use of differentiated instruction. Among these factors are the lack of content knowledge necessary to extend and differentiate the core curriculum content areas; the lack of time to adjust the curriculum for the students with SEN, or those with gifts and talents; teachers' difficulty to locate and use effectively the appropriate resources; and even their perception that students do not differ in how they learn (Hertberg-Davis, 2009; Van Tassel-Baska, \& Stambaugh, 2005). With regard to students with special needs/ disabilities many research studies 
in differentiated instruction report a lack of curriculum modifications in mainstream classrooms for these students (Buckley, 2005; Strogilos \& Stefanidis, 2015; Strogilos, Tragoulia, \& Kaila, 2015), and consequently, according to Scruggs, et al.'s (2007) literature review, the education of these students in general classrooms lacks appropriate teaching materials, differentiation in activities and opportunities for individualizing the curriculum. Similarly, Wehmeyer, Lattin, Lapp-Rincker, and Agran (2003) indicated that teachers were adapting their materials in less than $3 \%$ of their observations for students with intellectual disabilities. Also, Strogilos, Tragoulia, and Kaila (2015) identified limited curriculum modifications for students with SEN in their descriptive observations in mainstream classrooms. In addition to the limited use of curriculum modifications in co-taught classrooms, teachers indicated a moderate endorsement towards the curriculum modifications for students with special needs/ disabilities (Strogilos \& Stefanidis, 2015).

With regard to the type of modifications and their effectiveness in general classrooms, Kurth and Keegan (2014), in their study on the development and use of curriculum modifications for students with special needs/ disabilities, reported that classroom teachers produced modifications of lower quality and clarity than special educators and teaching assistants. In addition, they found that experienced teachers created more simplified modifications in comparison to novice teachers who created more functional alternative modifications. Kern and her colleagues (2001) found that when teachers use curricular modifications, students' on-task behavior and work production improved. Similarly, Lee et al. (2010) found that when curriculum modifications are used, students with special needs/ disabilities increased their engagement in academic-related responses and decreased their problematic behaviors. The authors also indicated that when curriculum modifications are used, teachers performed fewer classroom management activities. In a recent descriptive observational study in 65 inclusive classrooms, Morningstar, et al (2015) identified reductions (51\% of the observations) in the cognitive demands (i.e., completing fewer items, picture-based stories rather than written stories) of work for the students with SEN in almost half of these classrooms. Moreover, amongst the most frequent modifications for these students were changes in how materials were presented $(31 \%)$, environmental adjustments (23\%), and response alternations $(25 \%)$.

Even though many researchers agree that effective inclusion occurs when teachers modify the curriculum to the needs of all students, limited knowledge exists about the types and the quality of modifications understood and used by teachers. In this presentation, I will provide examples of differentiated activities for students with and without disabilities based on the principles of differentiated instruction. In addition, I will present the basic criteria with examples for planning and implementing individual adaptations for students with special needs/ disabilities.

\section{Conclusion}

Even though research has identified several challenges in the delivery of differentiated instruction, it is still considered an effective and useful approach in the education of all students. To this end, I will complete my presentation by indicating important prerequisites for the integration of differentiated instruction such as (a) policy makers to include differentiated instruction at the National Curriculum-Policy level; (b) universities to include relevant courses on teachers' pre-service and in-service training; and (c) schools to encourage the development of 
differentiated instruction as the main approach/ practice for the inclusion of students with disabilities.

\section{References}

Booth, T., \& Ainscow, M. (2013). Index for inclusion ( $3^{\text {rd }}$ ed). Bristol: Centre for Studies on Inclusive Education.

Buckley, C. (2005). Establishing and maintaining collaborative relationships between regular and special education teachers in middle school social studies inclusive classrooms. In Advances in learning and behavioral disabilities: Vol. 18. Cognition and learning in diverse settings, edited by

Thomas E. Scruggs, \& Margo Mastropieri (pp. 153-198). Oxford, UK: Elsevier.

Department for Education and Skills. (2003). Every child matters (Green Paper). London: DfES.

European Commission (2009). Strategic framework for education and training. Brussels: European Commission. Electronic source available online at: http://ec.europa.eu/education/lifelong-learning-policy/doc28_en.htm (accessed 28-01-2013).

Ferguson, D. L. (2008). International trends in inclusive education: The continuing challenge to teach each one and everyone. European Journal of Special Needs Education , 23(2), 109 - 120. Forbes, F. (2007). Towards inclusion: an Australian perspective. Support for Learning. 22(2), 66-71.

Hertberg-Davis, H. (2009). Myth7: Differentiation in the Regular Classroom Is Equivalent to Gifted Programs and Is Sufficient: Classroom Teachers Have the Time, the Skill, and the Will to Differentiate Adequately. Gifted Child Quarterly, 53: 251-253.

Janney, R. E., \& Snell, M. E. (2006). Modifying schoolwork in inclusive classrooms. Theory into practice, 45(3), 215-223.

Kern, L., Delaney, B., Clarke, S., Dunlap, G., \& Childs, K. (2001). Improving the classroom behavior of students with emotional and behavioral disorders using individualized curricular modifications. Journal of Emotional and Behavioral Disorders, 27, 615-631.

King-Sears, M. E. (2008). Facts and fallacies: Differentiation and the general education curriculum for students with special educational needs. Support for Learning, 23(2), 55-62.

Kurth, J. A., \& Keegan, L. (2014). Development and use of curricular adaptations for students receiving special education services. The Journal of Special Education, 48(3), 191-201 
Lee, S., Wehmeyer, M. L., Soukup, J. H., \& Palmer, S. B. (2010). Impact of curriculum modifications on access to the general education curriculum for students with disabilities. Exceptional Children, 76 (2), 213-233.

Morningstar, M. E., Shogren, K. A., Lee, H, \& Born, K. (2015). Preliminary lessons about supporting participation and learning in inclusive classrooms. Research and Practice for Persons with Severe Disabilities, 40(3), 192-210.

Nind, M. \& Wearmouth, J. (2006). Including children with special educational needs in mainstream classrooms: implications for pedagogy from a systematic review. Journal of Research in Special Educational Needs, 6(3), 116-124.

Scruggs, T. E., Mastropieri, M. A., \& Kimberly A. McDuffie, K. A. (2007). Co-teaching in inclusive classrooms: A metasynthesis of qualitative research. Exceptional Children 73(4), 392416.

Slee, R. (2013). How do we make inclusive education happen when exclusion is a political predisposition? International Journal of Inclusive Education, 17(8), 895-907.

Slee, R. (2010). The irregular school. Exclusion, schooling and inclusive education. London: Routhledge.

Stangvik, G. (2010). Special education in society and culture: comparative and developmental perspectives. European Journal of Special Needs Education, 25(4), 349-358.

Strogilos, V., \& Stefanidis, A. (2015). Contextual antecedents of co-teaching efficacy: Their influence on students with disabilities' learning progress, social participation and behaviour improvement. Teaching and Teacher Education, 47, 218-229.

Strogilos, V., Tragoulia, E., Avramidis, E., Voulagka, A., \& Papanikolaou, V. (2017). Understanding the development of differentiated instruction for students with and without disabilities in co-taught classrooms, Disability \& Society. http://www.tandfonline.com/doi/abs/10.1080/09687599.2017.1352488

Strogilos, V., E. Tragoulia., \& Kaila, M. (2015). Curriculum issues and benefits in supportive cotaught classes for students with intellectual disabilities. International Journal of Developmental Disabilities, 61(1), 32-40.

Tomlinson, C. A. (2001). How to differentiate instruction in mixed ability classrooms $\left(2^{\text {nd }}\right.$ ed.). Alexandria, VA: ASCD.

Tomlinson, C. A. (2003). Differentiating instruction for academic diversity. In J. M. Cooper (ed.) Classroom teaching skills, pp.149-180. Boston: Houghton Mifflin. 
UNESCO. (1994). The Salamanca Statement and Framework for Action on Special needs Education. Paris: UNESCO. Electronic source available online at: http://www.unesco.org/education/pdf/SALAMA_E.PDF (accessed 18-08- 2017).

UNESCO.(2001). The open file of inclusive education. Paris: UNESCO.

United Nations. (2006). Convention on the Rights of Persons with Disabilities. New York: United Nations.

US Department of Education. (2004). Individuals with Disability Education Act. Washington, DC: US Department of Education.

Van Tassel-Baska, J., \& Stambaugh, T. (2005). Challenges and possibilities for serving gifted learners in the regular classroom. Theory Into Practice, 44(3), 211-217.

Wehmeyer, M. L. (2011). Access to general education curriculum for students with significant cognitive disabiltities. In J. M. Kauffman and D. P. Hallahan. (Eds.). Handbook of Special Education (pp. 544-556). London: Routledge.

Wehmeyer, M. L., Lattin, D. L., Lapp-Rincker, G., \& Agran, M. (2003). Access to the general curriculum of middle school students with mental retardation. Remedial and Special Education, 24(5), 262-272.

Zigmond, N., \& Kloo, A. (2011). General and special education are (and should be different). In J. M. Kauffman and D. P. Hallahan. (Eds.). Handbook of Special Education (pp. 544-556). London: Routledge.

\section{Short bio:}

Vasilis Strogilos is an assistant professor in the National Institute of Education at Nanyang Technological University in Singapore. He has earned his PhD from the School of Education at the University of Birmingham in UK. He has experience as a special educator in English and Greek schools. In higher education, he has worked as a researcher at the University of the Aegean/ Greece, as an online tutor at the Roehampton London Online University and at the Greek Open University, and as a lecturer and assistant professor at the University of Thessaly/ Greece. His teaching and research have focused on special and inclusive education. His recent research interests have centered on the development of inclusive pedagogy and curricula with a specific interest on co-teaching and differentiation, and on multidisciplinary collaboration as a means to inclusion for students with severe and multiple disabilities. He has participated in a number of research projects and has published research articles and studies in peer-reviewed journals, books, and conference proceedings. 